\title{
Occurrence of two autochthonous cases of American cutaneous leishmaniasis in the neighborhood of Caju, city of Rio de Janeiro, Brazil ${ }^{*}$
}

\author{
Fred Bernardes Filho ${ }^{1,2}$ \\ Leonardo de Medeiros Maier ${ }^{4}$
}

\author{
Danielle Cristine Bonatto ${ }^{1,2}$ \\ José Augusto da Costa Nery ${ }^{1,5}$
}

Gustavo Martins ${ }^{3}$
Luna Azulay-Abulafia ${ }^{1,6}$

DOI: http://dx.doi.org/10.1590/abd1806-4841.20143539

\begin{abstract}
American cutaneous leishmaniasis is in full geographic expansion in Brazil and it is considered among the infectious and parasitic diseases of utmost importance worldwide, not only by its frequency, but mainly by therapeutic difficulties, deformities and sequelae that may result. In the state of Rio de Janeiro, the first autochthonous case of American cutaneous leishmaniasis was registered by Rabello in 1913. The authors report two cases of the disease in the region around the Cemetery São Francisco Xavier, in the Caju neighborhood, Rio de Janeiro city, and emphasize the need for actions that aim to early diagnosis and treatment of American cutaneous leishmaniasis cases.
\end{abstract}

Keywords: Leishmaniasis, cutaneous; Leishmaniasis, visceral; Psychodidae

American cutaneous leishmaniasis (CL) is a non contagious infectious disease of eminently chronic progression, caused by several species of protozoan of the Leishmania genus that affect the skin and/or mucosae of humans and of different species of wild and domestic animals of tropical and subtropical regions. ${ }^{1,2} \mathrm{CL}$ is, according to the World Health Organization, among the most important infectious and parasitary diseases, not only for its wide geographic distribution but also by the number of people affected every year. ${ }^{3}$ It is transmitted to animals and humans through the bite of several species of female phlebotomous sand flies. ${ }^{1}$

In Brazil, the disease presents two epidemiological patterns: epidemics associated with deforestation and leishmaniasis non associated with deforestation; migratory process, occupation of slopes and agglomerations in the outskirts of urban centers. The possible adaptation of vectors and parasites to modified environments and reservoirs has been discussed. ${ }^{2,45}$ In the state of Rio de Janeiro, the CL transmission pattern is predominantly domiciliary or peridomiciliary. ${ }^{4}$
The ulcer is the most frequent presentation of $\mathrm{CL}$; it is painless and usually located on exposed skin areas, with a round or oval shape, measuring from a few millimeters to some centimeters. ${ }^{1,2}$ It has an erithematous base, infiltrated and of hard consistency; welldelimited raised borders; a reddish background with coarse granulations. The bacterial infection associated with it may cause local pain and produce serouspurulent exudate that when dry forms scabs that totally or partially cover the ulcer floor.,

In the state of Rio de Janeiro, the first autochthonous case of cutaneous leishmaniasis was registered by Rabello in 1913. In the following years, Dutra and Silva (1915) reported the occurrence of the disease in the Realengo, Jacarepaguá and Gávea neighborhoods. In 1922, Aragão, Cerqueira and Vasconcelos investigated the first focus of CL in Águas Férreas, in the city of Rio de Janeiro. After this outbreak there were reports of the disease in other cities in the state of Rio de Janeiro, which did not arouse much interest of the health institutions, since they were confined to a few rural areas of the state. In

Received on 18.03.2014.

Approved by the Advisory Board and accepted for publication on 14.05.2014.

* Work carried out at the Institute of Dermatology Professor Rubem David Azulay, Santa Casa da Misericórdia do Rio de Janeiro (IDPRDA-SCMRJ) - Rio de Janeiro (RJ), Brazil.

Conflict of interest: None

Financial funding: None

Instituto de Dermatologia Professor Rubem David Azulay, Santa Casa da Misericórdia do Rio de Janeiro (IDPRDA-SCMRJ) - Rio de Janeiro (RJ), Brazil.

Pontifícia Universidade Católica do Rio de Janeiro (PUC RJ) - Rio de Janeiro (RJ), Brazil.

Private Clinic - Ituiutaba (MG), Brazil.

Hospital Municipal Rocha Maia (City Hospital Rocha Maia) - Botafogo (RJ), Brazil.

Instituto Oswaldo Cruz - Fundação Oswaldo Cruz (FIOCRUZ) - Rio de Janeiro (RJ), Brazil.

Universidade do Estado do Rio de Janeiro (UERJ) - Rio de Janeiro (RJ), Brasil.

C 2014 by Anais Brasileiros de Dermatologia 
1970 the endemic disease once again called attention, as some disease foci appeared in several cities in the state. Since the 70s the endemic disease was concentrated, in the city of Rio de Janeiro, in the western region, where the Maciço da Pedra Branca is located. In 1986 there was an outbreak of the disease in the municipality of Mesquita, on the border between the municipalities of Nova Iguaçu and Rio de Janeiro, in the area occupied by the Maciço do Gericinó. This region presented a profile similar to the Maciço da Pedra Branca, regarding the type of deforestation and occupation. ${ }^{4}$

In September 2013, the authors diagnosed two cases of American cutaneous leishmaniasis in the region around the Cemetery of São Francisco Xavier, in Caju neighborhood, city of Rio de Janeiro, Brazil (Figure 1). A 42-year-old female patient and a 52-yearold male patient presented a single ulcer, with erythematous-infiltrated raised edges for around three weeks on the right leg; both had used oral antibiotics without improvement of the lesions. A ulcer border imprint was made and May-Grunwald Giemsa and Leishman colorations evidenced amastigote forms of Leishmania sp (Figure 2). The biopsies of ulcer borders showed pseudo-carcinomatous hyperplasia, mixed inflammatory diffuse infiltrate with beginning granulomatous formation and dilated blood vessels. A polymerase chain reaction (PCR) for Leishmania was carried out in paraffin blocks, with negative results in the examined samples. The patient mentioned that
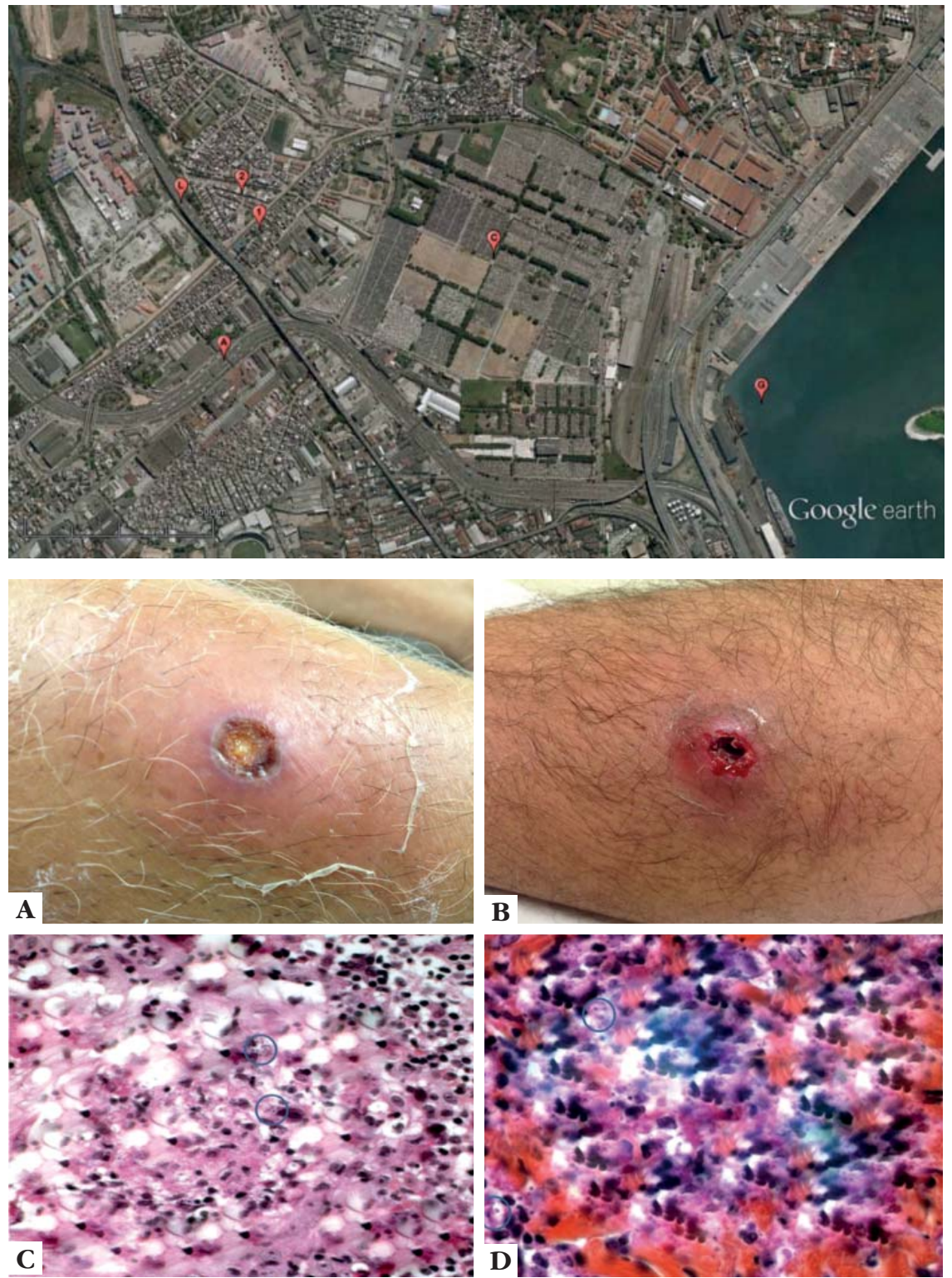

FIGURE 1:

Current map of the region around the Cemetery of São Francisco Xavier, in Caju neighborhood, city of Rio de Janeiro, Brazil. 1 and 2: places where two American cutaneous leishmaniasis cases were found; A: Avenida Brasil; C: Cemetery of São Francisco Xavier; G: Guanabara Bay; L: Linha Vermelha (President João Goulart / RJ-071 Express Way). Scale bar: 500 m. Source: Google Earth

FIGURE 2:

(a) Ulcer with raised outer borders on the external surface of the right leg - female patient; (b) Ulcer with erithematous-infiltrated and raised borders, on the external surface of the right leg - male patient; (c) ulcer border imprint, patient of case 1 , demonstrating the presence of amastigote forms of Leishmania sp - blue circle (May-Grunwald Giemsa coloration); (d) ulcer border imprint, patient of case 2, demonstrating the presence of amastigote forms of Leishmania sp - blue circle (Leishman coloration)bar: $500 \mathrm{~m}$. Source: Google Earth 
her mother lives close to the Maciço da Pedra Branca, but that she had not been in that region for over two months; the male patient reported that he lived and worked only in Caju neighborhood. Such facts characterize the description of two CL cases in an area considered free from the disease. The cases were notified and the treatment begun with meglumine antimoniate, in a dose of $15 \mathrm{mg} \mathrm{Sb} / \mathrm{kg} /$ day. After 20 days of treatment, the lesions were completely healed.

In June 2011, visceral leishmaniasis (VL) cases were confirmed in dogs from the Caju neighborhood, a port region in the city of Rio de Janeiro. Parasitological examination confirmed that those animals had been infected by Leishmania chagasi and entomological assessment conducted at that location evidenced the presence of the Lutzomyia longipalpis Vector. In January 2013, the first human case was confirmed in a resident of Caju neighborhood, revealing the first urban focus with transmission of human and canine VL in the city of Rio de Janeiro. ${ }^{7}$

\section{REFERENCES}

1. Brasil. Ministério da Saúde. Secretaria de Vigilância em Saúde. Manual de Vigilância da Leishmaniose Tegumentar Americana. 2. ed. atual. Brasília: Ministério da Saúde; 2007. 180 p. - (Série A. Normas e Manuais Técnicos).

2. Brito AC, Azulay DR, Azulay RD. Leishmaniose e demais protozooses de interesse dermatológico. In: Azulay RD, Azulay DR, Azulay-Abulafia L, editores. Dermatologia. Rio de Janeiro: Guanabara Koogan; 2013. p. 533-43.

3. WHO.int [Internet]. World Health Organization. Leishmaniasis: worldwide epidemiological and drug access update [cited 2013 Sep 30]. Disponível em: http://www.who.int/leishmaniasis/resources/Leishmaniasis_worldwide_epidemiological_and_drug_access_update.pdf

4. Magalhães RRSG. A leishmaniose tegumentar: estudo do $1^{\circ}$ foco ocorrido na cidade do Rio de Janeiro [dissertação]. Rio de Janeiro (RJ): Fundação Instituto Oswaldo Cruz; 2001.

5. Fernandes NC, Morgan I, Maceira JP, Cuzzi T, Noe RAM. American tegumentary leishmaniasis: hospitalized cases in Rio de Janeiro. An Bras Dermatol. 2004:79:431-9.

6. Brasil. Ministério da Saúde. Secretaria de Vigilância em Saúde. Departamento de Vigilância Epidemiológica. Atlas de leishmaniose tegumentar americana: diagnósticos clínico e diferencial. Brasilia: Ministério da Saúde; 2006. 136 p. (Série A. Normas e Manuais Técnicos).

7. Crmvri.org [Internet]. Secretaria Municipal de Saúde e Defesa Civil do Rio de Janeiro. Subsecretaria de Atenção Primária, Vigilância e Promoção da Saúde. Superintendência de Vigilância em Saúde. Nota Técnica № 2/2013 S/SUBPAV/SVS [acesso 08 abr 2014]. Disponível em: http://www.crmvrj.org.br/wp-content/uploads/2013/05/jornalout2011.pdf
There is no description of CL cases in Caju neighborhood, characterizing originality of the findings in this article. The opinion of the authors is that, despite the negative PCR result for Leishmania, the CL diagnosis in the two cases is established by the presence of amastigote forms of Leishmania $s p$ in the ulcer border imprint. The basic issue in this publication is the identification of CL cases in an area without description of the disease, except for the fact reported for the first and only time in 1913, by Rabello: therefore, 100 years passed without the description of autochthonous cases of CL in Rio de Janeiro (1913 - 2013). As a reason of its importance in public health and with the objective of emphasizing the need for actions that aim at the early diagnosis and treatment of human cases, the publication of this article is of interest.

\section{ACKNOWLEDGEMENT}

Rilza Beatriz Gayoso de Azevedo Coutinho $\square$

\author{
MAILING ADDRESS: \\ Fred Bernardes Filho \\ Rua Marquês de Caxias, $n^{\circ} 9$ - Sobrado - Centro \\ 24030-050 - Niterói - RJ \\ Brazil \\ E-mail:f9filho@gmail.com
}

How to cite this article: Bernardes Filho F, Bonatto DC, Martins G, Maier LM, Nery JAC, Azulay-Abulafia L. Occurrence of two autochthonous cases of American cutaneous leishmaniasis in the neighborhood of Caju, city of Rio de Janeiro, Brazil. An Bras Dermatol. 2014;89(5):848-50. 